\title{
Characteristics of the summit lakes of Ambae volcano and their potential for generating lahars
}

\author{
P. Bani ${ }^{1,2}$, J.-L. Join ${ }^{1}$, S. J. Cronin ${ }^{3}$, M. Lardy ${ }^{1}$, I. Rouet ${ }^{1,2}$, and E. Garaebiti ${ }^{4}$ \\ ${ }^{1}$ Institut de Recherche pour le Développement, BP A5 98848, Nouméa Cedex, New Caledonia \\ ${ }^{2}$ Pôle Pluridisciplinaire de la Matière et de l'Environnement, Université de la Nouvelle Calédonie, BP R4, Nouméa, \\ New Caledonia \\ ${ }^{3}$ Volcanic Risk Solutions, Institute of Natural Resources, Massey University, Private Bag 11 222, Palmerston North, \\ New Zealand \\ ${ }^{4}$ Geohazards, Department of Geology Mines and Water Resources, Port Vila, Vanuatu
}

Received: 24 February 2009 - Revised: 9 August 2009 - Accepted: 14 August 2009 - Published: 25 August 2009

\begin{abstract}
Volcanic eruptions through crater lakes often generate lahars, causing loss of life and property. On Ambae volcano, recent eruptive activities have rather tended to reduce the water volume in the crater lake (Lake Voui), in turn, reducing the chances for outburst floods. Lake Voui occupies a central position in the summit caldera and is well enclosed by the caldera relief. Eruptions with significantly higher magnitude than that of 1995 and 2005 are required for an outburst. A more probable scenario for lahar events is the overflow from Lake Manaro Lakua bounded on the eastern side by the caldera wall. Morphology and bathymetry analysis have been used to identify the weakest point of the caldera rim from which water from Lake Manaro Lakua may overflow to initiate lahars. The 1916 disaster described on south-east Ambae was possibly triggered by such an outburst from Lake Manaro Lakua. Taking into account the current level of Lake Manaro Lakua well below a critical overflow point, and the apparently low potential of Lake Voui eruptions to trigger lahars, the Ambae summit lakes may not be directly responsible for numerous lahar deposits identified around the Island.
\end{abstract}

\section{Introduction}

Ambae Island (also known as Aoba) is the emerged part of the most voluminous volcano of the Vanuatu archipelago (Fig. 1), with $3900 \mathrm{~m}$ height from the seabed and a volume of $2500 \mathrm{~km}^{3}$. A pronounced NE-SW trending rift zone dotted with scoria cones gives the $16 \times 38 \mathrm{~km}$ island an elongated form. A broad pyroclastic cone containing three lakes is lo- cated at the summit of this shield volcano within the youngest of at least two nested calderas formed less than 2000 years ago (Warden, 1970). Lake Voui is one of the largest acid crater lakes worldwide $\left(2.04 \mathrm{~km}^{2}\right)$ located $1400 \mathrm{~m}$ above sea level. Since the phreatic eruption in 1995 (e.g., Robin et al., 1995), after more than 300 years being dormant, Ambae volcano receives increasing attention - many authors have pointed out that Ambae is the most dangerous volcano in Vanuatu (Cronin et al., 2004; Monzier et Robin, 1995; Garaebiti, 2000; Bani et al., 2004). Robin and Monzier (1995) have pointed out that numerous and thick lahar deposits, probably not older than 100-320 years, occurred on both coasts in the central part of Ambae. The recent Surtseyan eruption (Lardy et al., 2005; Garaebiti et al., 2005; Nemeth et al., 2006) - beginning on the 27 November 2005, lasted almost two months. It was a minor event on a world scale, but one of the larger eruptions of the volcano in its short-record of volcanic activity. The eruption built up a tephra/tuff cone within the Lake Voui, which progressively isolated the active vent from the water, enabling the volcanic gas emissions directly into the atmosphere. $\mathrm{SO}_{2}$ flux measurements results indicate high emissions during and following the eruption period with significant impact on vegetation. The scale of explosions during this event never reached the point where water was laterally ejected from the Lake Voui and no lahar was generated. This eruption has focussed attention on the island lahar hazard assessment, which has not taken full cognisance of the characteristics of the summit lakes and of potential lahar origins. New contributions of this work are the bathymetry of crater lakes, summit morphology, lake water volumes their potential for generating lahars.

Correspondence to: P. Bani

(philipson.bani@noumea.ird.nc)

Published by Copernicus Publications on behalf of the European Geosciences Union. 


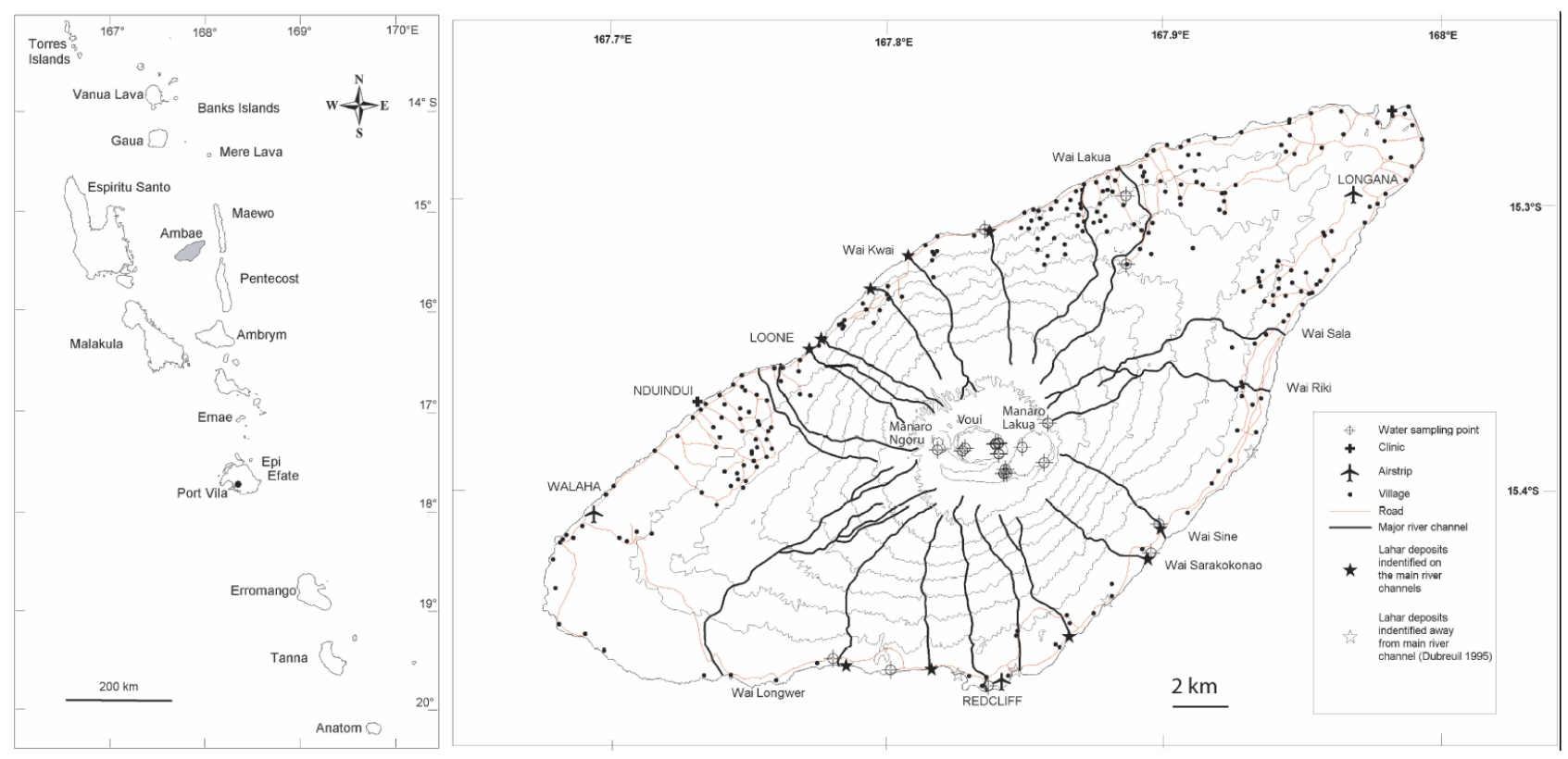

Fig. 1. Left panel, Vanuatu archipelago with Ambae Island in grey. Right panel, Ambae Island showing major river catchments, villages and roads. The summit lakes are labelled. Notice that a water outburst from the eastern part of Manaro Lakua is a threat to villages between Wai Sine and Wai Riki. Note the positions of the water sampling sites at the summit and on the coast.

\section{Methods}

We used a $40 \mathrm{~m}$ digital elevation model (DEM), obtained from 1/50000 topographic map, to determine the summit morphology, the structural lineaments and delineate the major flow paths on Ambae Island. Field surveys were carried out to identify lahar-prone flow channels and lahar deposits. SPOT satellite data were use to complement to field survey. We refer to the term lahars as a group of volcanic debris flow (fairly uniform mixtures of water and $>50 \%$ by volume of solids - e.g., Vallance, 2000). To evaluate the potential of the Ambae summit lakes for generating past lahars, we carried out field surveys on lake Voui and lake Manaro Lakua. Hydrographical data were obtained using an inflatable boat with depth sounders and GPS positioning device. Waters from lakes and tributaries, as well as from springs and creeks around the massif volcano were sampled and analysed using ICP-OES for cations and Technicon Auto-Analyzer for $\mathrm{SO}_{4}$ and $\mathrm{Cl}$. We refer to the Piper diagram to distinguish surface water from ground water - mineralised crater lake water are also well discriminated with this diagram (e.g., Cruz and França, 2006). We use the Shoeller diagram to determine the importance of chemistry changes in water in relation to the volcanic activities. $\mathrm{SO}_{2}$ flux measurements were carried out using miniaturised Differential Optical Absorption Spectroscopy (Platt, 1994) carried alternatively on board a CESSNA 206G and a Britten-Norman Islander.

\section{Results}

\subsection{Lakes Bathymetry and water volume}

Bathymetry results obtained in this work (Fig. 2) indicate a generally shallower lake Manaro Lakua contrasting with the deep lake Voui. Two depth points of around $20 \mathrm{~m}$ were identified in Manaro Lakua, close to the eastern margin. Its calculated water volume is $17 \times 10^{6} \mathrm{~m}^{3}$ with a surface area of $2.08 \mathrm{~km}^{2}$. Lake Voui has a similar surface area $\left(2.04 \mathrm{~km}^{2}\right)$ but a volume of $40 \times 10^{6} \mathrm{~m}^{3}$ of water. The deepest point in Voui was identified as c. $120 \mathrm{~m}$, located in the middle of the lake. Regularly, bubbles are sighted above this point (Fig. 3) - and in 2005, this point was the principal site of the eruptive activity. Manaro Ngoru, to the west of Voui is a periodically dry shallow lake that may contain up to $0.05 \times 10^{6} \mathrm{~m}^{3}$ of water.

The summit of Ambae volcano thus hosts more than 57 million cubic meters of water, $70 \%$ of which is acidic and is contained within lake Voui.

\subsection{Summit morphology}

Figure 4 highlights the locations of the 3 lakes at the summit of Ambae volcano. The distance between Manaro Lakua and Voui is $200 \mathrm{~m}$ and there is around $450 \mathrm{~m}$ between Voui and Manaro Ngoru. Lake Voui occupies the center of Ambae summit and is located $2.5 \mathrm{~km}$ from the caldera margins. The Lake Voui water surface is located $100 \mathrm{~m}$ below the Voui crater rim and close to $200 \mathrm{~m}$ from the caldera rim. Manaro 


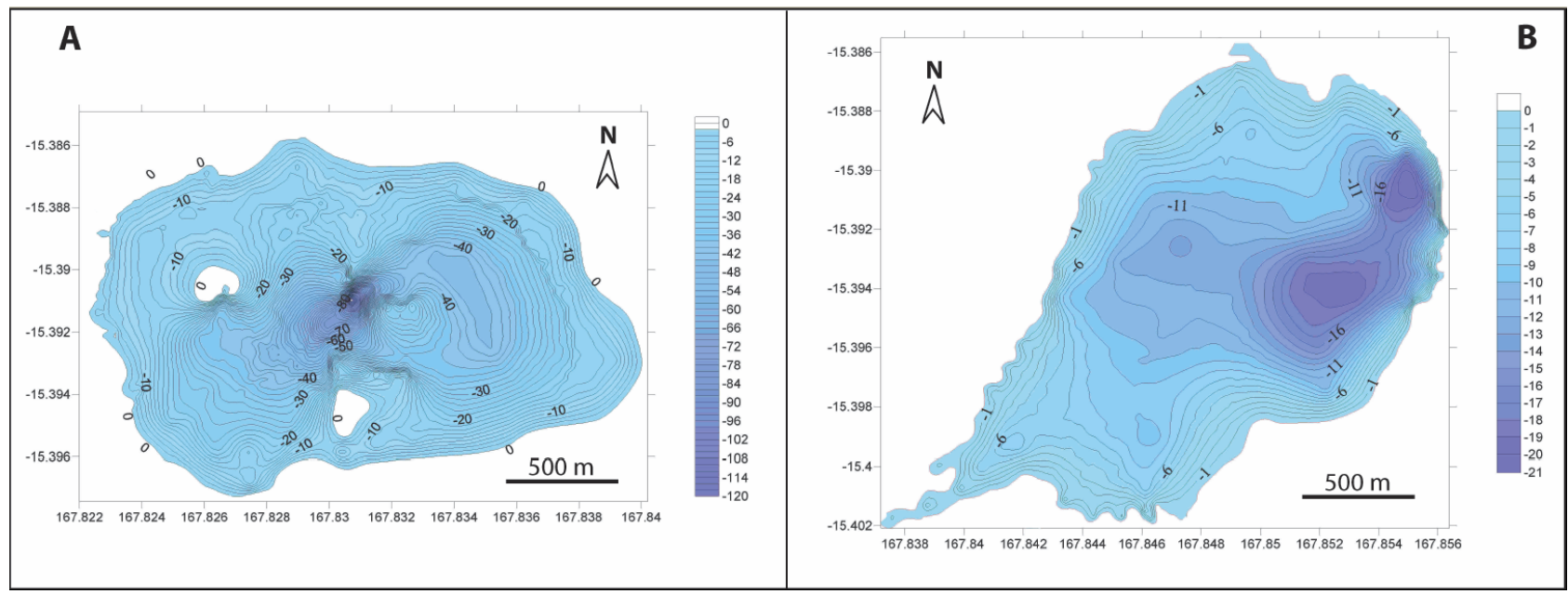

Fig. 2. (A) Bathymetry of crater lake Voui with its deepest point $(\sim 120 \mathrm{~m})$ in the center of the lake. Bathymetry data points were obtained in 1996 (Lardy et al., 1997) and recalculated for this paper. (B) Bathymetry of Manaro Lakua. Note the deepest points ( $20 \mathrm{~m})$ to the east of the lake. Data were obtained in 2005.

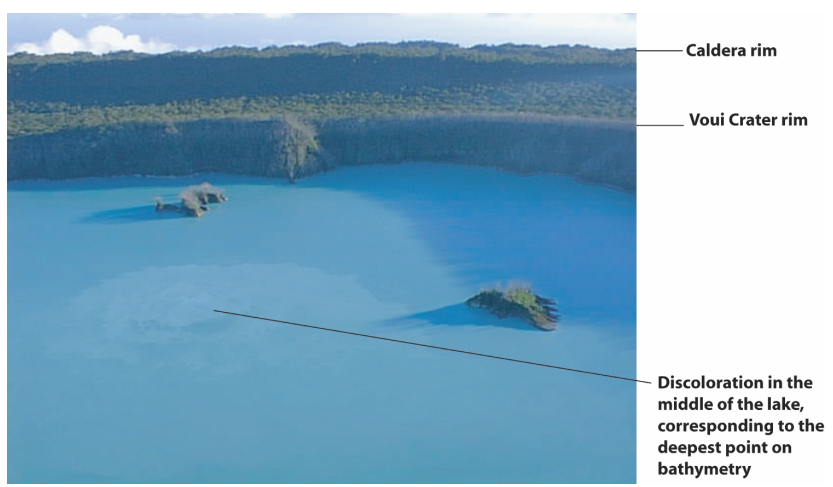

Fig. 3. Lake Voui in 2000, with a discoloration on top of the deepest point identified on bathymetry and suggesting hydrothermal discharge into the lake.

Lakua is perched $10-20 \mathrm{~m}$ above lake Voui; its eastern side is bounded by the caldera margin. The Manaro Lakua water level is typically around $100 \mathrm{~m}$ below the caldera rim, except in its eastern portion where this drops to only $60 \mathrm{~m}$ (Fig. 5). The lowest bounding rim occurs over around $400 \mathrm{~m}$ of the lake margin, potentially being the most likely location for water outbursts from the summit area. The periodically dry Manaro Ngoru is more than $700 \mathrm{~m}$ from the caldera rim and is protected by more than $100 \mathrm{~m}$ relief to the west.

Caldera limits on Ambae are relatively well characterized; isolating the main streams within the caldera from the drainage outside it. The closest distinctive channels from the summit lakes begin $500 \mathrm{~m}$ to the east and southeast (Fig. 1) of the lakes.

\subsection{Water chemistry}

A total of 27 water samples were collected on Ambae (Fig. 1) and analysed in this work. Results are summarised in Table 1. The Piper diagram (Fig. 6a) indicates differences in water chemistry between summit lakes, springs and creeks of Ambae. Water from springs (ground water) can be distinguished by their relatively high content in $\mathrm{SiO}_{2}$. Water from creeks (surface water) are enriched in $\mathrm{Cl}-\mathrm{Na}$, while Voui and Manaro Lakua appear enriched with $\mathrm{MgSO}_{4}$ due to the magmatic-hydrothermal mechanisms. Close to the east bank of Manaro Lakua, water sampled over an active solfatara, presents similar characteristics as lake Voui.

Between 2005 and 2006, Voui and Manaro Lakua have experienced increases in chemical concentrations (Fig. 6b) in accordance with the end-2005 eruption (e.g., Nemeth et al., 2006). $\mathrm{SO}_{2}$ flux results obtained during this period exceed the $1000 \mathrm{t} / \mathrm{d}$ and fluctuated in accordance to the volcanic activity (Bani et al., 2009).

\subsection{Volcaniclastic deposits}

Along the coast of Ambae volcano, sixteen out of the main flow channels delineated from the DEM were visited along with 10 sites of volcaniclastic deposits along the coast. These sites range from 5 to $12 \mathrm{~km}$ from the summit. Channels slopes are very steep, commonly 20-25\%. Deposits identified at the stream mouths are poorly sorted, containing particles that range from clay to boulder-size (Fig. 7). The clast lithologies include coarse blocky dense and vesicular debris apparently derived from pyroclastic cones and basaltic flows in the north and from similar undifferentiated volcanics in the south of the island. Deposits are generally preserved in small areas, (less than $100 \mathrm{~m}$ wide), except for those at Wai 


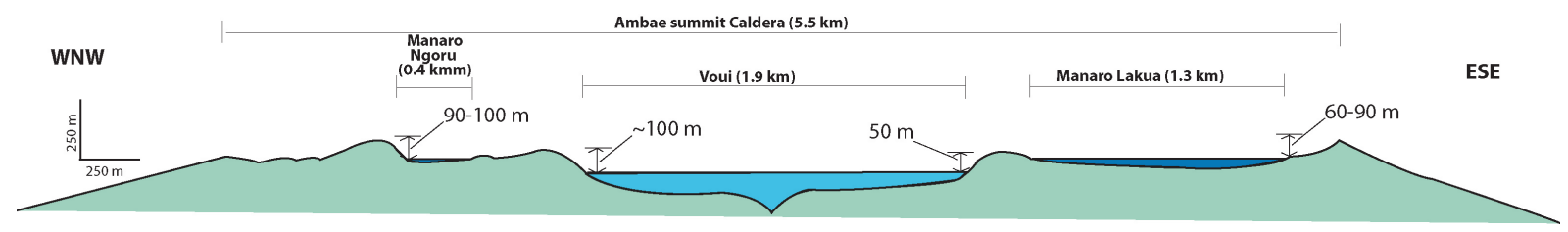

Fig. 4. Summit topographic WNW-ESE profile. Note the location of Voui in the centre of the summit caldera and Manaro Lakua close to the caldera margin. Manaro Ngoru water volume is negligible in comparison to the two other summit lakes.

Table 1. Water analysis results showing concentration of $\mathrm{Ca}, \mathrm{Mg}, \mathrm{Na}, \mathrm{K}, \mathrm{Cl}, \mathrm{SO}_{4}, \mathrm{NO}_{3}$ and $\mathrm{SiO}_{2}$ outside caldera and chemistry changes in summit lakes.

\begin{tabular}{|c|c|c|c|c|c|c|c|c|c|c|c|c|}
\hline & Site & Date & $\mathrm{pH}$ & $\begin{array}{c}\text { Cond } \\
\left(\mathrm{mS}-25^{\circ} \mathrm{C}\right)\end{array}$ & $\begin{array}{c}\mathrm{Ca} \\
(\mathrm{mg} / \mathrm{L})\end{array}$ & $\begin{array}{c}\mathrm{Mg} \\
(\mathrm{mg} / \mathrm{L})\end{array}$ & $\begin{array}{c}\mathrm{Na} \\
(\mathrm{mg} / \mathrm{L})\end{array}$ & $\begin{array}{c}\mathrm{K} \\
(\mathrm{mg} / \mathrm{L})\end{array}$ & $\begin{array}{c}\mathrm{Cl} \\
(\mathrm{mg} / \mathrm{L})\end{array}$ & $\begin{array}{c}\mathrm{SO}_{4} \\
(\mathrm{mg} / \mathrm{L})\end{array}$ & $\begin{array}{c}\mathrm{NO}_{3} \\
(\mathrm{mg} / \mathrm{L})\end{array}$ & $\begin{array}{c}\mathrm{SiO}_{2} \\
(\mathrm{mg} / \mathrm{L})\end{array}$ \\
\hline \multirow{10}{*}{ 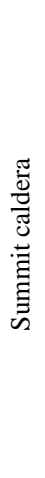 } & \multirow{4}{*}{ Lake Voui } & $16 / 07 / 05$ & 1.6 & 14486 & 148.48 & 514.27 & 160.49 & 40.08 & 1012.17 & 3755.68 & & 82.11 \\
\hline & & $12 / 12 / 05$ & 2.8 & 18720 & 280.4 & 1293.7 & 241 & 2.2 & 1562 & 5409 & & 345 \\
\hline & & 17/01/06 & 2.3 & 20460 & 382.4 & 1263.4 & 299.6 & 60.4 & 1615 & 6504 & & 300.3 \\
\hline & & $27 / 02 / 06$ & 2.5 & 16860 & 304.13 & 1043.2 & 249.5 & 68.1 & 1410.6 & 4499 & & 699.8 \\
\hline & \multirow[t]{3}{*}{ Lake Manaro Lakua } & $07 / 10 / 05$ & 5.5 & 86.7 & 5.48 & 2.43 & 4.31 & 2.59 & 11,01 & 2.92 & 0.69 & 4.19 \\
\hline & & 17/01/06 & 4.2 & 107 & 3.6 & 5.5 & 3.6 & 1.3 & 10.8 & 30.7 & & 2,5 \\
\hline & & $27 / 02 / 06$ & 4 & 66.5 & 3.7 & 6.3 & 6.4 & 1.3 & 10.5 & 39.2 & & 3 \\
\hline & Lake Manaro Ngoru & $12 / 12 / 05$ & 6.3 & 93 & 5.65 & 3.35 & 9.1 & 1.45 & 7.1 & 22.7 & 1.05 & 6 \\
\hline & Water on Solfatara & $15 / 07 / 05$ & 2.1 & 7960 & 144.51 & 89.64 & 25.62 & 11.01 & 488.65 & 666.57 & 0.59 & 173.22 \\
\hline & Stream to the north of Lakua & $17 / 07 / 05$ & 6.9 & 120 & 10.48 & 5.71 & 5.06 & 2.22 & 3.26 & 9.24 & 0.06 & 21.56 \\
\hline$\frac{\pi}{3}$ & Vandue - ground water & 07/06/05 & 5.6 & 149 & 14.68 & 4.23 & 6.23 & 3.72 & 7.31 & 6.26 & 1.47 & 21.06 \\
\hline $\bar{\Xi}$ & Ambanga - ground water & $17 / 07 / 05$ & 7 & 260 & 9.6 & 4.23 & 7.75 & 46.88 & 6.62 & 2.82 & 0.06 & 22.92 \\
\hline & Redcliff - ground water & 07/09/05 & 5.5 & 86.7 & 5.48 & 2.43 & 4.31 & 2.59 & 11.01 & 2.92 & 0.69 & 4.19 \\
\hline
\end{tabular}

Kwai and Wai Sine (Fig. 1) where they extent to a few hundred meters wide and are more than $10 \mathrm{~m}$ thick. Tree moulds are abundant within the deposits. Volcanoclastic deposits are reported also occur elsewhere on the island flanks (Dubreuil, 1995).

\section{Discussion}

\subsection{Potential caldera outburst point}

Base on summit morphology (Fig. 5) and bathymetry (Fig. 2), Manaro Lakua is a dammed-lake, formed after the emplacement of Voui cone. It also bounds the caldera wall and is most likely to generate potential over flow, in contrast to the central positions of Voui and Manaro Ngoru. The eastern lake shore abuts the lowest point of the caldera rim and the water level is $60 \mathrm{~m}$ below it. The edge of the lake is less than $100 \mathrm{~m}$ from the caldera margin (Fig. 5), which is formed pyroclastic deposits (tuff) on top of basaltic lava flows. The two deepest points in Manaro Lakua are also located close to the eastern edge (Fig. 2) contentrating up to $1 / 3$ of the 17 million tons of water and thus pressurising this portion of the caldera wall. Lake Manaro Lakua and lake Voui have no outlets and the evident controls on the water balance are rainfall, evaporation and eruption. According to Spiers (2005) the hydrographical balance estimated for both Manaro Lakua and Voui implies an overall surplus of $\sim 10^{6} \mathrm{~m}^{3} \mathrm{y}^{-1}$ outside volcanic manifestation periods, suggesting a possible subsurface seepage to maintain equilibrium in lakes under an average annual rainfall of $5000 \mathrm{~mm} \mathrm{y}^{-1}$ (Wiart et al., 2003). Tree trunks standing in up to $1 \mathrm{~m}$ of water, suggest a gradual water level rise in Manaro Lakua, or at least long-term variation in this level over periods of several decades (Fig. 8). With $2.08 \mathrm{~km}^{2}$ of water surface in Manaro Lakua, a minimum $125 \times 10^{6} \mathrm{~m}^{3}$ of water is necessary to reach the lowest point of the caldera rim and assuming that the surplus 


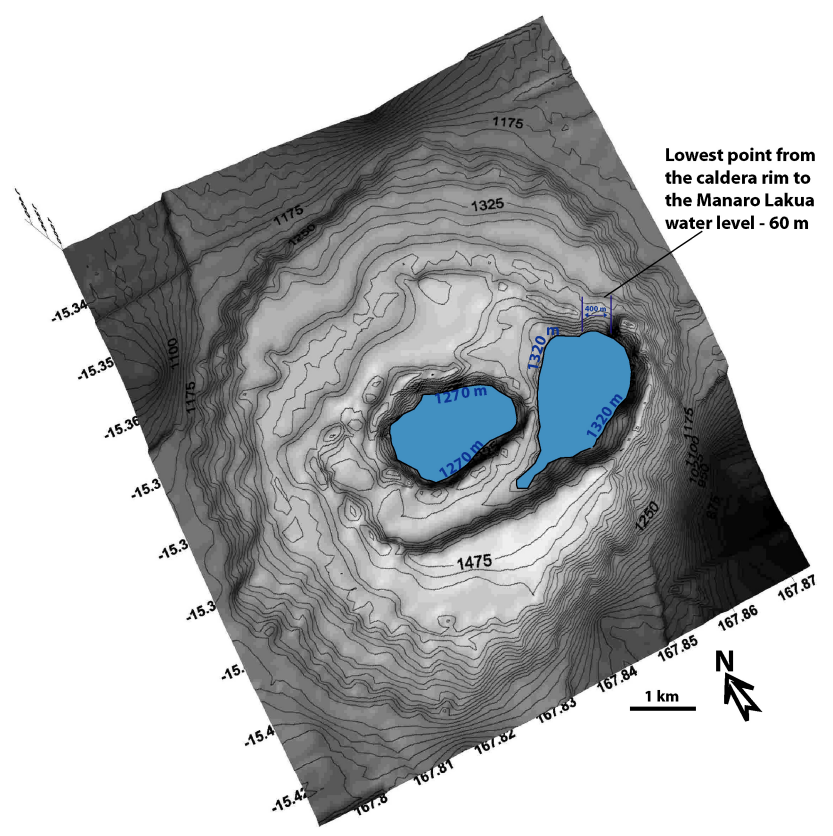

Fig. 5. Morphology of the Ambae summit showing the narrowest and lowest point to the east of Manaro Lakua lake. Note the lowest caldera limit and the reduced volume of the caldera wall to the east of Lakua. DEM generated from existing 1:50 000 topographic map.

calculated for Voui and Manaro Lakua is proportional to the lake surfaces, 2.5 centuries would be necessary to reach the caldera rim. Extraordinary rainfalls during the frequent cyclones in this area may also have strong influence.

If overflow occurs from Manaro Lakua, it will follow catchments mainly between Wai Riki and Wai Sine to the east and south-east of Ambae Island (Fig. 1). Around 1916, according to De la Rüe (1945), water from the Ambae summit forced his way through the caldera wall, leading to an avalanche of water that destroyed an entire village on the south-east, killing around one hundred people. The author did not mention any concurrent volcanic activity and referred to the summit as an ancient crater. The direct connection between this event and Manaro Lakua Lakua is extremely difficult to confirm, however the location of the disaster and the absence of volcanic activity supports the potential of a Manaro Lakua overflow. Circumstantially, the time required to fill Manaro Lakua from empty to its critical level, taking into account the hydrographical balance of Spiers (2005) is around 300 years. This is similar to the time lag between the formation of Voui cone in 1575 (Warden, 1970) and the 1916 disaster on south-east Ambae.

\subsection{Eruption intensity and lahar events, Lake Voui}

With $40 \times 10^{6} \mathrm{~m}^{3}$ of water, Voui is among the most voluminous acid crater lakes worldwide. It is around ten times larger than Ruapehu's Crater Lake (Christenson and Wood, 1993), which has had a long history of destructive lahars produced directly by explosive phreatomagmatic eruptions (Cronin et al., 1997). Chemical changes in Ambae summit lakes, particularly lake Voui (Fig. 6), reflect magmatic volatile inputs. Escape of steam and other gases from shallow magma provided raw data to forecast the chemistry of volcanic lakes. Absorption of ascending magmatic vapour containing acidic gases $\left(\mathrm{SO}_{2}, \mathrm{HCl}, \mathrm{HF}\right)$ produces low-pH solutions (Table 1) that discharge into the lakes (Delmelle and Bernard, 2000). These solutions dissolved silicate rocks and subsequently enriched the lakes with chemical components leached from rocks (Table 1, Fig. 6). Lake Voui is thus the uppermost manifestation of a hydrothermal reservoir between the surface and an underlying magma. Hydrothermal fluids transited through the unique vent highlighted in Fig. 2.

Voui lake with 40 million tons of water above an active volcanic vent, constitutes a serious volcanic hazard to over $30 \%$ of the 10000 inhabitants of Ambae island (Cronin et al., 2004; Monzier et Robin, 1995; Garaebiti, 2000; Bani et al., 2004). An eruption within Voui, water and lake sediments mixed with high-temperature volcanic gases and pyroclastic materials can be mobilized and jetted onto the slopes at high speed, giving rise to destructive lahars. However recent volcanic manifestations, including the phreatic eruption in 1995 (e.g., Robin et al., 1995) and the surseyan eruption in 2005 (Lardy et al., 2005; Garaebiti et al., 2005; Nemeth et al., 2006) were not large enough to trigger any lahar. The lake water level dropped to $7 \mathrm{~m}$ in March-April 1995 during the phreatic eruption (Wiart et al., 2003), an equivalent of $14.3 \times 10^{6} \mathrm{~m}^{3}$ in lost water, corresponding to more than $36 \%$ of Voui's volume. In 2005, the eruption was more intense but occurred during the rainy season (November-March) and in June 2006, 5 months after the eruption, a $6 \mathrm{~m}$ drop was indicated, indicating a minimum $30 \%$ water loss.

Recent volcanic activities on Ambae tend to reduce the water volume, thus reducing the chances for outburst with eruptive activity in the immediately following period. Eruptions with higher magnitude, such as those that formed the Voui cone in 1575 (Warden, 1970), are probably required to trigger lahars, or those that generate large enough surges to induce volume changes and trigger large seiche-like waves in the neighbouring Manaro Lakua.

\subsection{Lake Manaro Ngoru}

With only $0.05 \times 10^{6} \mathrm{~m}^{3}$ of water during rainy season, and its location within a deep portion of the central caldera, Manaro Ngoru presents minor threat to Ambae population. Water chemistry indicates only minor influences from volcanic discharge, suggesting a system relatively isolated from Voui.

\subsection{Other potential source for lahar events}

Taking into account the relatively long periods required for lake Lakua to reach overflow levels at the caldera rim, the 


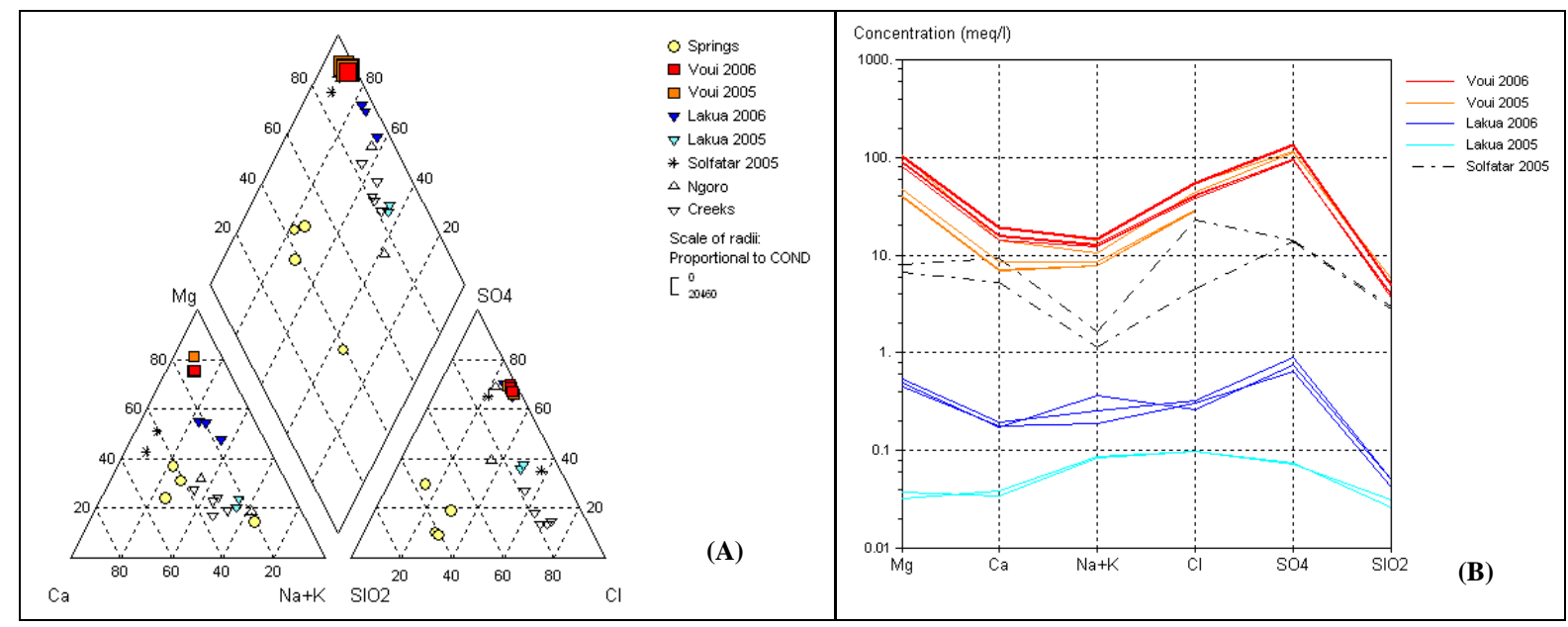

Fig. 6. Piper diagram (A) of water analysis indicates relative abundance of $\mathrm{SiO}_{2}$ in underground water. Water from creeks (surface water)

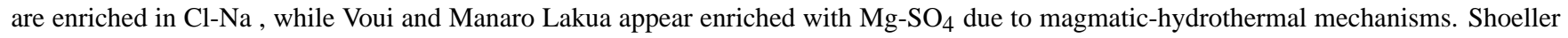
diagram (B) shows the evolution of water composition in both Voui and Manaro Lakua.

low number of large eruptive events to trigger lahars from Lake Voui, it is likely that many other lahar generation mechanisms occur on Ambae to explain the numerous lahar deposits identified by Robin and Monzier (1994) and shown in Fig. 7. Among the possible triggering mechanisms include, (1) outbursts from subsurface seepage during heavy rainfall events, explaining the surplus of one million cubic meters of water each year. Although water sampling did not show any link between Voui and spring water (Fig. 6), acidic water from Voui can dissolve rock during seepage leading to alteration which in turn increases the potential of masse failure, as it has been described at Rincon de la Vieja volcano (Kempter and Rowe, 2000). (2) Vegetation cover loss by gas and tephra fall, for example, $\mathrm{SO}_{2}$ release from the summit crater between November 2005 and August 2006 have led to $15-20 \mathrm{~km}^{2}$ vegetation damage to the north-west of Ambae, following prevailing wind directions (http://www.ulb.ac.be/sciences/cvl/aoba/Ambae1.html). Reducing the vegetation coverage in this sector exposes the high-steepened flank surface to erosion and thus leads to an increase of flank vulnerability, which may subsequently contribute to lahar generation. (3) Magma emplacement and dyke intrusion are other trigger factors of cone failure (Beloussov, 1999; Elsworth and Day, 1999). Voluminous lava flows and thick tephra deposits around Ambae suggest that magmatic events have been more intense in the past and have contributed to some extend to flank destabilization. A similarly structured island of the same size, Taveuni, in Fiji has experienced also several flank failure, probably also related to tectonic activity and dyke intrusion along the central rift axis (Cronin and Neall, 2001). Eruptions with higher magnitude that generate large enough surges to induce volume changes and trigger large seiche-like waves in the neighbour- ing Manaro Lakua, rainfall-remobilization and masse failure in relation to numerous structural lineaments of Ambae are other potentials for lahars.

\section{Conclusions}

Volcanic eruptions through crater lakes are often accompanied by lahars, causing loss of life and properties. However on Ambae volcano, historical eruptive activities have significantly reduced the water volume in the crater lake Voui, which in turn reduced the chances for an outburst to trigger lahar. Voui central position in the summit means that only eruptions with significantly higher magnitude than that of 1995 and 2005 are required for ejection of water from the lake and onto outer volcano flanks. More probable scenario for lahars is the overflow from Lake Manaro Lakua. Morphology and bathymetry analysis have identified the weakest point of the caldera limits from which water may flow and initiate lahars. The 1916 disaster described on southeast Ambae was possibly triggered by such a flow from Manaro Lakua. Taking into account the long period required for lake Lakua to reach the critical water level, the low number of eruptive events and the potential of Voui to trigger lahar, other mechamism were highly likely for generating numerous lahar deposits occurring around the volcano. 

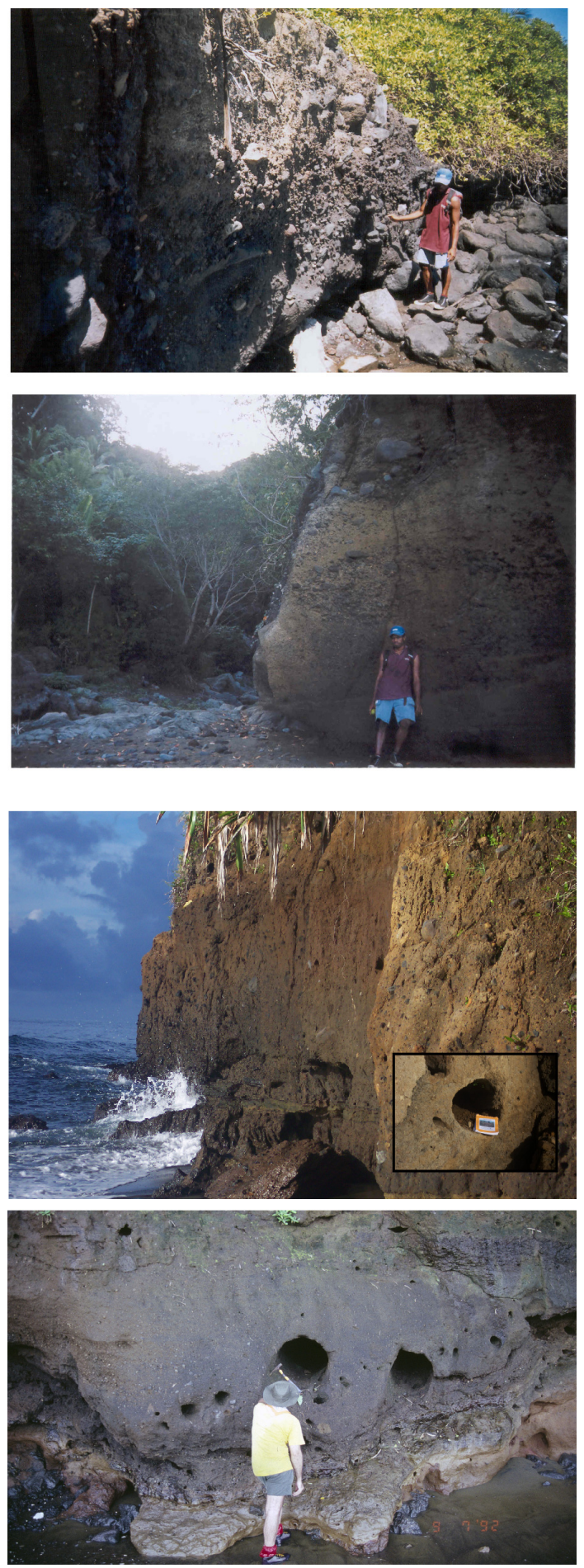

Fig. 7. Representative lahar deposits identified on Ambae volcano. 1 - Deposit from a debris flow emplaced close to Wai Kwae, north Ambae; 2 - deposit of hyperconcentrated stream flow identified at Loone, nord-west Ambae; 3, 4-deposits of debris and hyperconcentrated flows with tree-trunks emplacement to the sector between Wai Sine and Wai Riki, South Ambae.

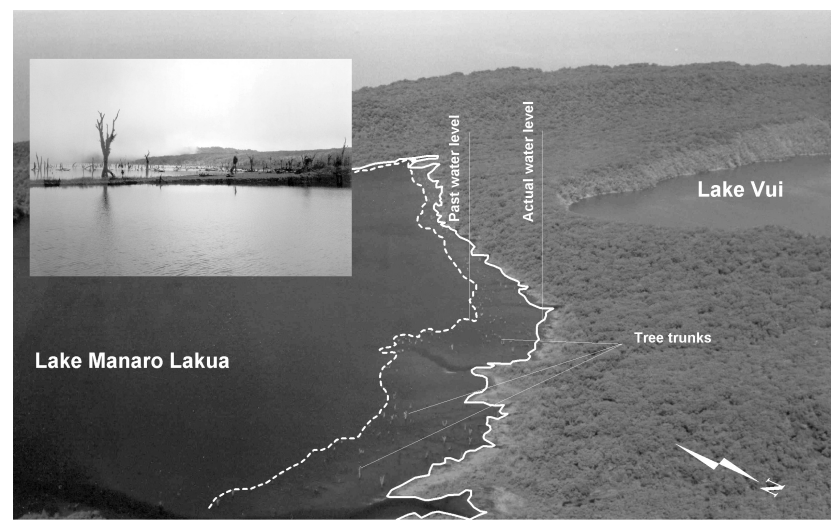

Fig. 8. Progressive water level rise in Manaro Lakua. Note the numerous tree trunk in the water delimiting the ancien water lavel. A photograph of the tree-trunks is provided on the top-left picture.

Acknowledgements. This work was supported by the trilateral disaster relief arrangements in the Pacific (FRANZ) with the help of DGMWR and NDMO. We gratefully acknowledge Agence de Développement Economique de la Nouvelle Calédonie - ADECAL (P.B., J-L.J., M.L) and NZ FRST MAUX0401 (SJC). Many thanks to $\mathrm{S}$. Allen for the constructive comments of the previous version of this manuscript. Also acknowledge the anonymous reviewers.

Edited by: J. Marti

Reviewed by: S. Allen and another anonymous referee

\section{References}

Bani, P., Oppenheimer C., Varekamp, J. C., Quinou, T., Lardy, M., and Carn, S.: Remarkable geochemical changes and degassing at Voui crater lake, Ambae volcano, Vanuatu, J. Volcanol. Geoth. Res., under review, 2009.

Bani, P., Lardy, M., Rouet, I., and Garaebiti, E.: Les risques des lahars sur l'île d'Aoba, Vanuatu. Session des posters, Assisses de la Recherche Française dans le Pacifique, 24-27 août, Map, 2004.

Belousov, A., Belousova, M., and Voight, B.: Multiple edifice failures, debris avalanches and associated eruptions in the Holocene history of Shiveluch volcano, Russia, Bull. Volcanol. 61, 324 342, 1999.

Christenson, B. W. and Wood, C. P.: Evolution of a vent-hosted hydrothermal system beneath Ruapehu Crater Lake, New Zealand, B. Volcanol., 55, 547-565, 1993.

Cronin, S. J., Neall, V. E., Lecointre, J. A., and Palmer, A. S.: Changes in Whangaehu River lahar characteristics during the 1995 eruption sequence, Ruapehu volcano, New Zealand, J. Volcanol. Geoth. Res., 76, 47-61, 1997.

Cronin, S. J. and Neall, V. E.: Holocene volcanic geology, volcanic hazard and risk on Taveuni, Fiji, New Zeal. J. Geol. Geop., 44, 417-437, 2001.

Cronin, S. J., Gaylord, D. R., Charley, D., Asalloway, B. V., Wallez, S., and Esau, J. W.: Participatory methods of incorporation scientific with traditional knowledge for volcanic hazard management on Ambae Island, Vanuatu. Bul. Volc., 66, 652-668, 2004. 
Cruz, J. V. and França, Z.: Hydrogeochemistry of thermal and mineral water springs of the Azores archipelago (Portugal), J. Volcanol. Geoth. Res., 151, 382-398, 2006.

De la Rüe, A.: Les Nouvelles Hebrides, Îles de Cendres et de Corail, Montréal : Les Editions de l'arbre, Collection France Forever, B.411 et 474, 252 pp., 1945.

Delmelle, P. and Bernard, A.: Volcanic Lakes, in: Encyclopedia of volcanoes, edited by: Sigurdsson, H., Houghton, B., McNutt, S. R., Rymer, H., and Stix, J., Academic Press, 877-895, 2000.

Dubreuil, N.: Dynamismes eruptifs et pétro-geochimie de l'île d'Aoba (Vanuatu), arc insulaire des Nouvelles Hébrides, Université de Bretagne Occidentale, Brest, Rapport de D.E.A, 56 pp., 1995.

Elsworth, D. and Day, S. J.: Flank collapse triggered by intrusion: the Canarian and Cape Verde Archipelagos, J. Volcanol. Geoth. Res., 94, 323-340, 1999.

Garaebiti, E.: Analyse morphologique des Risques Volcaniques d'Aoba (Vanuatu). Département de Sciences de la Terre, Université Blaise Pascal - Clermont-Ferrand, France, Travail d'étude et de Recherche 1999-2000, 30 pp., 2000.

Garaebiti, E., Charley, D., Harrison, D., Wallez, S., Lardy, M., Bani, P., Join, J. L., Robin, C., Scott, B., Sherburn, S., Cronin, S., and Bernard, A.: New eruption begins on 27 November 2005 and builts cone in the crater lake, 11/2005 BGVN 30:11, 2005.

Kempter, K. A. and Rowe, G. L.: Leakage of Active Crater lake brine through the north flank at Rincon de la Vieja volcano, northwest Costa Rica, and implications for crater collapse, J. Volcanol. Geoth. Res., 97, 143-159, 2000.

Lardy, M., Matera, M., and Charley, D.: Mission sur le Lombenben (AOBA) du 25 au 27 Novembre 1996 et Mesures bathymétriques du lac Voui, Document de Travail, mai 1997.
Lardy, M., Bani, P., Join, J. L., Robin, C., Scott, B., Sheburn, S., Garaebiti, E., Charley, D., Harrison, M., Wallez, S., and Cronin, S.: Rapport, Volcan Aoba, Vanuatu, Société Vocanologique Européenne, 6, 6-8, 2005.

Monzier, M. and Robin, C.: Volcanic hazard for Aoba Island, ORTSOM, Map, 1995.

Nemeth, K., Cronin, S. J., Charley, D., Harrison, M., and Garae, E.: Exploding lakes in Vanuatu - "Surtseyan-style" eruptions witnessed on Ambae Island, Episodes, 29, 87-92, 2006.

Platt, U.: Differential optical absorption spectroscopy (DOAS), in: Air monitoring by spectroscopic techniques, edited by: Sigrist, M. W., Wiley, New York, 27-84, 1994.

Robin, C., Monzier, M., Lardy, M., Regnier, M., Metexian, J.-P., Decourt, R., Charley, D., Ruiz, M., and Eissen, J.-P.: Increased steam emissions and seismicity in early February; evacuation preparations made, Aoba, Vanuatu, Bull. Global Volcanism Network, 20:02, 1995.

Robin, C. and Monzier, M.: Volcanic Hazards in Vanuatu, September, ORSTOM and Department of Geology, Mines and Water resources of the Vanuatu Gouvernement, Port Vila, Report, 15 pp., 1994.

Spiers, E.: L'eau dans les volcans: approche hydrogéologique de la zone sommitale du volcan Ambae (Archipel du Vanuatu), Rapport de stage de fin d'étude, 22 pp., 2005.

Vallance, J. W.: Lahars, in: Encyclopedia of Volcanoes, edited by: Sigurdsson, H., Academic Press, San Diego, 601-616, 2000.

Warden, A. J.: Evolution of Aoba caldera volcano, New Hebrides, Bulletin Volcanologique, 34, 1, 107-140, 1970.

Wiart, P., Lardy, M., Bani, P., Garaebiti, E., Tabbagh, J., and Halbwachs, M.: Active crater lake hazard management using on-site monitoring and DEM-based risk evaluation (Aoba island, Vanuatu), Cities On Volcanoes 3, Hawaii, July 14-18, 2003. 